\title{
Evaluation of some commercial formuilations against Spodoptera littoralis and Hypera brunneippennis larvae.
}

\author{
Narmen A. Youssef and Atef A. Abd-ELgayed \\ Dept. of Plant Protection, Fac. of Agriculture, Fayoum University, Fayoum, Egypt.
}

\begin{abstract}
The insecticidal activity of three commercial $\mathrm{Bt}$ - formulations and one fungus; namely DipelDf , W- Bus and Protecto (Bacillus thuringiensis var.kurstaki) and Biofly (Beauveria bassiana) were tested against $2^{\text {nd }}$ and $4^{\text {th }}$ instar larvae of Spodoptera littoralis (Boisd) and Hypera brunneipennis (Boheman) were studied under laboratory conditions. Results revealed that Bt- formulations caused the larval mortality after treatment of $S$. littoralis $2^{\text {nd }}$ and $4^{\text {th }}$ larval instars ranged from 40 to $100 \%$ and 32.5 to $92.5 \%$ and reached 100,85 and $100 \%$ for $H$. brunneipennis, respectively at the highest concentration after 7 days of treatment compared to $77.5 \%$ and $60 \%$ for S. littoralis and 95 and $85 \%$ for H. brunneipennis treatments by Biofly. The DipelDf and W-Bus were highly efficient on the insect larvae, followed by Biofly and Protecto, respectively. Based on the $\mathrm{LC}_{50}$ values, DipelDf was the highest toxic to $S$. littoralis and H. brunneipennis than that of the other compounds. Pupation and adults emergence percentages were reduced by all treatments compared to control.
\end{abstract}

Key words: Spodoptera littoralis ,Hypera brunneippennis, commercial products , efficiency

\section{Introduction}

Among chewing insect pests, Spodoptera littoralis (Boisd) (Lepidoptera: Noctuidae) is considered as an important sporadic pest in the world. It causes 25 $100 \%$ economic loss (Dhir et al., 1992; Prayogo et al., 2005 ) in crops based on crop stage and its population level in the field. The Egyptian alfalfa weevil ( EAW ), Hypera brunneipennis ( Boheman ) ( Coleoptera : Curculionidae) is considered to be the most serious and destructive pest of alfalfa in Egypt ( Al-Doghairi and Elhag, 2003). One annual generation is recorded in Egypt for the EAW (Hammad et al., 1967). The larval stage is the most damaging during the weevil life cycle. By feeding on the alfalfa plant's growing tips, the larvae cause skeletonization of leaves, stunting, reduced plant growth, and ultimate reduction in yield. The adults are also, foliar feeders, causing additional, but less significant, damage.

The widespread and intensive use of different synthetic insecticides for controlling this pest increased environmental problems such as insect resistance, excessive persistence of residues, human health hazards and harmful effect on the non- target organisms. From this point of view, it is necessary to minimize the application of pesticides that considered as a main source of environmental pollution and use other compounds may proof as good alternatives of insecticides. In recent years, crop protection based on biological control of crop pests with microbial pathogens as virus, bacteria, fungi and nematodes were considered as valuable tools in pest management (Bhattacharya et al., 2003). Entomopathogenic fungi may proof, also, as valuable and play an important role in integrated pest management programs. (El- Hawary and Abd El-
Salam, 2009) reported that fungal biological control agents have demonstrated efficacy against a wide range of insect pests including $S$. litura. Successful use of fungal pathogens in pest control depends on selection of right virulent fungal strain formulated in proper way and applied at an appropriate dose against susceptible host stage under favorable environmental conditions (Asi et al., 2012).Among the entomopathogenic agents, also, the most widely used biopesticides are subspecies and strains of Bacillus thuringensis (Bt). B. thuringensis is a sporeforming bacterium well- known for its insecticidal properties due to its ability to produce crystal inclusions during sporulation. Each strain of this bacterium specifically kills one or a few related species of insect larvae such as Lepidopteran, Dipteran and Coleopteran (Haggag, 2013). Commercial Bt products, generally, consist of a mixture of spores and crystals, produced in large fermenters and applied as foliar sprays, much like synthetic insecticides (Sanchis et al., 1999). It is known that most Bt formulations have a very short residual activity. The persistence of $\mathrm{Bt}$. spores show an obvious reduction after few days of exposure to weather, and reduction in its viability was progressively correlated with the time elapsed after exposure in the field. The pathogen is not mobile and cannot escape under the unfavorable conditions. (Mohamed et al., 2010) .

In the present experiments, the effectiveness of several bioinsecticides against the cotton leafworm $S$. littoralis and alfalfa weevil, $H$. brunneipennis was determined with the intention to find out the best compounds for controlling these economic pests in an integrated pest management program.

Material and Methods 


\section{Tested insects:}

A- S.littoralis

The cotton leafworm larvae of S.littoralis were obtained from Agricultural Research Centre, Cairo, Egypt, and were reared on fresh leaves of caster bean (Ricinus communis) under laboratory conditions of $25 \pm 2 \mathrm{C}^{\circ}$ and $65 \pm 5 \% \mathrm{R}$.H..(Adham et al., 2009 and Kamel et al., 2010). As larvae reached the $2^{\text {nd }}$ and $4^{\text {th }}$ instars, they were used in the experiments.

\section{B- H.brunneipennis}

Alfalfa weevil larvae were collected, early in the morning, by using an insect sweepnet in an alfalfa field at Fayoum Government. Insects, were reared on fresh alfalfa plants ( Medica gosativa L. ) at laboratory conditions of $25 \pm 2 \mathrm{C}^{\circ}, 65 \pm 5 \%$ R.H.and $2^{\text {nd }}$ and $4^{\text {th }}$ instars of the weevils larvae were selected for experiments.

\section{Tested compounds}

Commercial formulations of the following insecticides tested against $2^{\text {nd }}$ and $4^{\text {th }}$ instar larvae of S.littoralis and H. brunneipennis were obtained from the Agricultural Research Centre, Cairo, Egypt.

DipelDf ( WP ) $6.4 \%$ : commercial product formulation contains $32 \times 10^{3} \mathrm{IU} / \mathrm{mg}$ of Bacillus thuringiensis var. kurstaki; W-Bus (WP) $8 \%$ : commercial product formulation contains $8 \times 10^{3} \mathrm{IU} /$ $\mathrm{mg}$ of Bacillus thuringiensis var. kurstaki, Protecto (WP) 9.4\%:commercial product formulation contains $32 \mathrm{X} 10^{6} \mathrm{IU} / \mathrm{mgof}$ Bacillus thuringiensis var .kurstaki and Biofly ( WP) : commercial product formulation contains $30 \times 10^{6}$ spores/ mg of Beauvera bassiana.

\section{Bioassay}

The insecticidal activities of the tested Btformulations and fungi, each at four concentrations were prepared in distilled water and tested against $2^{\text {nd }}$ and $4^{\text {th }}$ instar larvae of S.littoralis and $H$. brunneipennis larvae using the dipping leaf technique (Ahmed, 2009). The leaves were first washed with distilled water and dipped in solution of the desired concentration of Bt or fungi commercial formulations (DipelDf, W-Bus, Protecto and Biofly ). Each leaf was dipped for 30 seconds, then placed individually in Petri- dishes ( $9 \mathrm{~cm}$ diameter ) containing moistened filter papers to avoid desiccation of leaves. other castor bean leaves for treatment of $S$. littoralis and alfalfa for $H$. brunneipennus were treated with sterile distilled water for control. Then, ten larvae from each $2^{\text {nd }} /$ or $4^{\text {th }}$ instars larvae were separately placed in each Petri dish for each treatment. Four Petri- dishes were used as replicates for each treatment and control. Larvae were allowed to feed for $48 \mathrm{~h}$. on treated leaves. Then these leaves were removed and replaced by another untreated ones.All Petri -dishes were kept at the above mentioned conditions. Larvae were examined daily for 7 days after treatment to determine the mortality percentages. Accumlative larval mortality was recorded and corrected using Abbott's formula (1925). Afterwards, the corresponding concentration probit lines were estimated in addition to determining $50 \%$ mortalities and slope values of tested compounds were also estimated. Data were analyzed by ANOVA and the means were separated using the Duncan's multiple range test (Duncan, 1955).

Fourty newly hatched $2^{\text {nd }}, 4^{\text {th }}$ instar larvae of each S.lttoralis and $H$. brunneipennis were fed as previously described ( ten larvae/ four replicates ) on leaves treated with the calculated $\mathrm{LC}_{50}$ starting of exposure was 2 days after application for each of these compounds. The initial ( 2 days after application) and residual effect of $\mathrm{Bt}$ and fungi formulations at (4,6 and 8 days ) after application against larvae were recorded at the end of the experiment (6) days.

The surviving larvae were transferred to other clean Petri- dishes, and supplied with untreated fresh castor bean leaves until pupation. Pupation and adult emergence percentages after treatment by the $\mathrm{LC}_{50}$, and control were also determined.

\section{Results and Discussion}

Toxic effect of $\mathrm{Bt}$ and fungual formulations against $2^{\text {nd }}$ and $4^{\text {th }}$ instar larvae of S.littoralis and H. brunneipennis

Efficacies of the four concentrations of all tested insecticides on $2^{\text {nd }}$ and $4^{\text {th }}$ instar larvae of S.littoralis and $H$. brunneipennis at 7 day after treatment are presented in table 1. DipelDf, W-Bus and Protecto caused $100 \%$ mortality after treatment by highest concentration on the $2^{\text {nd }}$ instar larvae of $H$. brunneipennis while treatment of $4^{\text {th }}$ instar larvae caused 100, 90 and $85 \%$, respectively and 95, $85 \%$ mortality at Biofly. While the larval mortality was in the range 40 to 100 and 32.5 to $92.5 \%$ on $2^{\text {nd }}$ and $4^{\text {th }}$ instar larvae of $S$. littoralis, respectively at Bt formulations and $77.5,60 \%$ at Biofly. There were significant differences between the tested insecticides of both insects $(\mathrm{F}=75.08 ; \mathrm{df}=3$ for $S$. littoralis $)$ and $(\mathrm{F}=21.31 ; \mathrm{df}=3$ for $H$. brunneipennus), respectively at 7 days post treatment. Also, there were significant differences between concentrations and also significant between $2^{\text {nd }}$ and $4^{\text {th }}$ instar larvae of both insect species $(\mathrm{F}=38.18, ; \mathrm{df}=3$ forS.littoralis $)$ and $(\mathrm{F}=30.2, ; \mathrm{df}=3$ for $H$. brunneipennis), respectively 
Table 1. Accumulated corrected mortality percentages after 7 days of treatment by some commercial Bt and fungi formulations against $S$. littoralis and H. brunneipennis $2^{\text {nd }}$ and $4^{\text {th }}$ instar larvae.

\begin{tabular}{|c|c|c|c|c|c|}
\hline \multirow[t]{3}{*}{ Formulations } & \multirow[t]{3}{*}{ Conc.gm/L } & \multicolumn{2}{|c|}{ Spodoptera littoralis } & \multicolumn{2}{|c|}{ Hypera brunneipennis } \\
\hline & & \multicolumn{4}{|c|}{ Mortality $\%$} \\
\hline & & $2^{\text {nd }}$ & $4^{\text {th }}$ & $2^{\text {nd }}$ & $4^{\text {th }}$ \\
\hline \multirow[t]{4}{*}{ Dipel DF } & 0.5 & $55^{\mathrm{def}}$ & $45^{\mathrm{cde}}$ & $90^{\mathrm{ab}}$ & $75^{\mathrm{cd}}$ \\
\hline & 1 & $62.5^{\text {bcde }}$ & $60^{\mathrm{bc}}$ & $92.5^{\mathrm{a}}$ & $82.5^{\mathrm{bc}}$ \\
\hline & 2 & $87.5^{\mathrm{ab}}$ & $85^{\mathrm{a}}$ & $100^{\mathrm{a}}$ & $100^{\mathrm{a}}$ \\
\hline & 4 & $100^{\mathrm{a}}$ & $92.5^{\mathrm{a}}$ & $100^{\mathrm{a}}$ & $100^{\mathrm{a}}$ \\
\hline Mean & & $76.25^{\mathrm{a}}$ & $70.63^{\mathrm{a}}$ & $95.63^{\mathrm{a}}$ & $89.38^{\mathrm{a}}$ \\
\hline \multirow[t]{4}{*}{ W-Bus } & 0.5 & $52.5^{\mathrm{defg}}$ & $40^{\text {cde }}$ & $70 b^{c}$ & $60^{\text {efg }}$ \\
\hline & 1 & $57.5^{\text {cdef }}$ & $50^{\mathrm{cd}}$ & $90^{\mathrm{ab}}$ & $75^{\mathrm{cd}}$ \\
\hline & 2 & $60^{\text {cdef }}$ & $55^{\mathrm{bc}}$ & $100^{\mathrm{a}}$ & $82.5^{\mathrm{bc}}$ \\
\hline & 4 & $82.5^{\mathrm{abc}}$ & $77.5^{\mathrm{ab}}$ & $100^{\mathrm{a}}$ & $90^{\mathrm{ab}}$ \\
\hline Mean & & $63.13^{\mathrm{b}}$ & $55.63^{\mathrm{b}}$ & $90^{\mathrm{ab}}$ & $76.88^{\mathrm{b}}$ \\
\hline \multirow[t]{4}{*}{ Protecto } & 0.5 & $15^{\mathrm{g}}$ & $12.5^{\mathrm{g}}$ & $60^{c}$ & $50^{\text {gh }}$ \\
\hline & 1 & $22.5^{\mathrm{fg}}$ & $17.5^{\mathrm{fg}}$ & $65^{c}$ & $52.5^{\text {fgh }}$ \\
\hline & 2 & $27.5^{\mathrm{g}}$ & $25^{\mathrm{efg}}$ & $70^{\mathrm{bc}}$ & $65^{\text {def }}$ \\
\hline & 4 & $40^{\text {efg }}$ & $32.5^{\text {defg }}$ & $100^{\mathrm{a}}$ & $85^{\text {bc }}$ \\
\hline Mean & & $26.25^{\mathrm{c}}$ & $21.88^{\mathrm{d}}$ & $73.75^{\mathrm{c}}$ & $63.13^{c}$ \\
\hline \multirow[t]{4}{*}{ Biofly } & 1 & $40^{\mathrm{efg}}$ & $30^{\text {defg }}$ & $70^{\mathrm{bc}}$ & $45^{\mathrm{h}}$ \\
\hline & 2 & $50^{\mathrm{efg}}$ & $35^{\mathrm{def}}$ & $80^{\mathrm{abc}}$ & $57.5^{\text {efgh }}$ \\
\hline & 4 & $55^{\text {def }}$ & $42.5^{\text {cde }}$ & $90^{\mathrm{ab}}$ & $67.5^{\mathrm{de}}$ \\
\hline & 8 & $77.5^{\mathrm{abcd}}$ & $60^{\mathrm{bc}}$ & $95^{\mathrm{a}}$ & $85 b^{c}$ \\
\hline Mean & & $55.63^{b}$ & $41.88^{c}$ & $83.75^{\mathrm{bc}}$ & $63.75^{\mathrm{c}}$ \\
\hline $\begin{array}{l}\mathrm{F} \text { between treat. } \\
\text { concen. and ages }\end{array}$ & & 1.37 & 1.52 & 1.28 & 1.06 \\
\hline df & 15 & & & & \\
\hline $\begin{array}{l}\text { F between } \\
\text { concentrations }\end{array}$ & 38.18 & & & 30.2 & \\
\hline df & 3 & & & 3 & \\
\hline $\mathrm{F}$ between treatment & 75.08 & & & 21.31 & \\
\hline df & 3 & & & 3 & \\
\hline
\end{tabular}

Data presented in table 1 indicate that the mortality percentage after treatment of the $2^{\text {nd }}$ and $4^{\text {th }}$ instar larvae of S.littoralis and H. brunneipennis increased gradually with increasing concentrations of all the insecticides.

The present results revealed that the tested $\mathrm{Bt}$ and fungus formulations had insecticidal activity against $2^{\text {nd }}$ and $4^{\text {th }}$ instar larvae of S.littoralis and $H$. brunneipennis larvae, where DipelDf highly killed the insect larvae both insect species, followed by WBus, Biofly and Protecto, respectively. These results agree with Haggag, (2013) who reported that DipelDf, Dipel 2x and Delfin highly killed S.littoralis larvae , followed by Agry, Protecto and Agerin, respectively . Kaur (2000), also, reported that B.thuringiensis applied for controlling of lepidopteran, dipteran and coleopteran insects for decades. Herrnstadt and Soares (1989) reported that B.thuringiensis $7.6 \times 10^{7}$ spores/ml solution , caused $80 \%$ mortality against alfalfa weevil. The surviving weevil larvae were stunted and ceased feeding. Lower concentrations resulted in minimal levels of mortality, but caused significant levels of feeding inhibition, these inhibited larvae will not survive to adulthood in the field. B.thuringiensis produced more than $93 \%$ mortality on first instar larvae of Spodoptera frugiperda and Peridroma saucia (Alvarez et al. , 2009 ) . B.thuringensis Berliner is a promising agent for microbial control of agriculturally and medically important insects (Souza et al., 2009). The difference in activity might be due to the presence or absence of biologically active Cry toxins, their relative amounts and additive/ synergistic effect of these toxins in the formulations. Shelton et al., (1993). Karthikeyan and Selvanarayanan (2011) reported that the bioassay with $B$. bassiana against $S$. litura, percent 
mortality increased from 33.33 to 86.67 as the dose was increased from 0.15 to $0.25 \%$.

\section{Susceptibility test}

Table (2) reveals the $\mathrm{LC}_{50}$ values of the tested compounds against $2^{\text {nd }}$ and $4^{\text {th }}$ instar larvae of S.littoralis and $H$. brunneipennis recording $1.13 \& 1.47 ; 2.75 \& 6.47 ; 9.08 \& 14.90$ and $2.015,5.05$ $\mathrm{gm} / \mathrm{l}$, for DipelDf, W-Bus, Protecto and Biofly against $2^{\text {nd }}$ and $4^{\text {thinstar }}$ larvae of S.littoralis , respectively while those were $0.84,0.14 ; 0.59,0.44$; $1.94 \& 1.41$ and $2.53 \& 5.20$ for $H$. brunneipennis, respectively.

According to the $\mathrm{LC}_{50}$ values, DipelDf was the highest toxic to S.littoralis and H. brunneipennis than the other 3 compounds. The toxicity values of DipelDf was significantly higher than that others.

\section{Effects of $\mathrm{LC}_{50}$ of Bt and B.bassiana formulations} on pupation and adult emergence percentage.

The initial and residual effects of Bt and B.bassiana formulations at four time intervals ( $2,4,6$, and 8 days ) post application against $2^{\text {nd }}$ and $4^{\text {th }}$ instar larvae of S.littoralis and H. brunneipennus (at 6 days after treatment) are shown in tables (3 and 4). Data in table (3) revealed that, treatment with all the tested compounds reduced pupation and adults emergence percentages and, also, reduced the population of S.littoralis larvae compared to the control at initial and residual time intervals ( 2, 4,6 and 8 days ) to record $51,43.6,35.9$ and 38.5 at 2 time; $37.5,30,25$ and 27.5 at 4 days; $30,27.5,15$ and 20 at 6 days and 25.6, 20.5,7.7 and $12.8 \%$ larval mortalities at the 8 days, respectively on $2^{\text {nd }}$ instar larvae and recored 42.5, 37.5, 30and $32.5 ; 30,25$, 20 and $20 ; 20,17.5,7.5$ and $12.5 ; 17.5,15,5$ and 10 at ( $2,4,6$, and 8 days ), respectively on $4^{\text {th }}$ instar larvae.

The results in Table (3) indicated also that DipelDf and W-Bus decreased both pupation and adult emergence percentages at ( 2, 4, 6, and 8 days ) more than Biofly and Protecto compared to the control which recorded pupation and emergence rates of 97.5 and $100 \%$, respectively.

The results of reduction percentage of $H$. brunneipennis population, pupation and adult emergence percentages after four indicating time intervals are summarized in Table (4). Data showed that the mean percentage of cumulative larval mortality, pupation and adult emergence percentages of $H$. brunneipennis after four indicating time intervals of application(2, 4, 6, and 8days ) varied among the all treatments and control. The reduction was $60,55,40$, and 45; 45, 37.5, 20 and $25 \%$ larval mortality on the $2^{\text {nd }}$ instar larvae and $52.5,47.5,35$ and $47.5 ; 27.5,20,10$ and $15 \%$ larval mortality on the $4^{\text {th }}$ instar larvae at the initial time interval ( 2 day) and 6 days of application for DipelDf, WBus,Protecto and Biofly, respectively. These results agree with El-Ghar et al.,(1995) working with Bacillus thuringiensis and Abamectin against S.littoralis, with a pronounced decrease of pupation $(36 \%)$ after Abamectin treatment. Mohamed and Mahmoud, (2008) reported that the rates of pupation and the emergence of moths of S.littoralis were reduced by all tested insecticides ( Dipel 2x, Agrin, BioGuard, Biofly and Spinosad ), respectively as compared to the control. Beauveria bassiana caused significant decrease in pupal survival with the malformation among S.littoralis pupae (Emara and Hefnawy, 2000). Hyphomycete fungi cause fatal infection to the immature stages of S.littoralis, this may due to the disruption of normal metabolism, and damage of target tissues such as fat body or alter hormone balance (Meshrif et al., 2007).

From the above results and based on the $\mathrm{LC}_{50}$ values, DipelDf, proved as the highest toxic to S.littoralis and $H$. brunneipennis than that of the other compounds, followed by ,W-Bus,Biofly and Protecto.

Table2. Lethal concentration of Bt and fungi formulations against $S$. littoralis and $H$. brunnipennus larvae

\begin{tabular}{|c|c|c|c|c|c|c|}
\hline \multirow[t]{2}{*}{ Formulation } & \multicolumn{3}{|c|}{$\begin{array}{l}\text { S. littoralis } \\
\text { gm/L (spores/ml) }\end{array}$} & \multicolumn{3}{|c|}{$\begin{array}{l}\text { H. brunnipennus } \\
\text { gm/L (spores/ml) }\end{array}$} \\
\hline & & $2^{\text {nd }}$ & $4^{\text {th }}$ & & $2^{\text {nd }}$ & $4^{\text {th }}$ \\
\hline \multirow[t]{2}{*}{ Dipel DF } & $\mathrm{LC}_{50}$ & 1.13 & 1.47 & $\mathrm{LC}_{50}$ & 0.14 & 0.84 \\
\hline & slope & 3.07 & 2.34 & slope & 0.69 & 1.34 \\
\hline \multirow[t]{2}{*}{ W-Bus } & $\mathrm{LC}_{50}$ & 2.015 & 5.05 & $\mathrm{LC}_{50}$ & 0.44 & 0.59 \\
\hline & slope & 1.03 & 0.85 & slope & 0.39 & 1.48 \\
\hline \multirow[t]{2}{*}{ Protecto } & $\mathrm{LC}_{50}$ & 9.08 & 14.90 & $\mathrm{LC}_{50}$ & 1.41 & 1.94 \\
\hline & slope & 0.90 & 0.80 & slope & 1.12 & 1.24 \\
\hline \multirow[t]{2}{*}{ Biofly } & $\mathrm{LC}_{50}$ & 2.75 & 6.47 & $\mathrm{LC}_{50}$ & 1.20 & 1.53 \\
\hline & slope & 1.23 & 1.01 & slope & 1.40 & 1.63 \\
\hline
\end{tabular}


Table 3. Initial and residual effect of the tested $\mathrm{Bt}$ and fungual formulations against $2^{\text {nd }}$ and $4^{\text {th }}$ instar larvae of S. littoralis at 6 days after treatment

\begin{tabular}{|c|c|c|c|c|c|c|c|c|c|c|c|c|}
\hline \multirow{4}{*}{$\begin{array}{l}\text { Formul } \\
\text { ations }\end{array}$} & \multicolumn{12}{|c|}{ Accumulative larvae mortality $\%$ after indicated time intervals(days) } \\
\hline & \multirow{2}{*}{\multicolumn{3}{|c|}{$\begin{array}{c}\text { Initial kill } \\
\text { Accumulative } 2 \text { day }\end{array}$}} & \multicolumn{9}{|c|}{ Residual effect } \\
\hline & & & & \multicolumn{3}{|c|}{ Accumulative 4 day } & \multicolumn{3}{|c|}{ Accumulative 6 days } & \multicolumn{3}{|c|}{ Accumulative 8 days } \\
\hline & $\begin{array}{c}\text { \%Corr } \\
\text { ected } \\
\text { mortal } \\
\text { ity }\end{array}$ & $\begin{array}{l}\% \text { Pup } \\
\text { ation }\end{array}$ & $\begin{array}{c}\% \\
\text { Adults } \\
\text { emerg } \\
\text { ence }\end{array}$ & $\begin{array}{c}\text { \% Corr } \\
\text { ected } \\
\text { mortal } \\
\text { ity }\end{array}$ & $\begin{array}{l}\% \text { Pup } \\
\text { ation }\end{array}$ & $\begin{array}{c}\% \\
\text { Adults } \\
\text { emerg } \\
\text { ence }\end{array}$ & $\begin{array}{c}\text { \% Corr } \\
\text { ected } \\
\text { mortal } \\
\text { ity }\end{array}$ & $\begin{array}{l}\% \text { Pup } \\
\text { ation }\end{array}$ & $\begin{array}{c}\% \\
\text { Adults } \\
\text { emerg } \\
\text { ence }\end{array}$ & $\begin{array}{c}\text { \% Corr } \\
\text { ected } \\
\text { mortal } \\
\text { ity }\end{array}$ & $\begin{array}{l}\% \text { Pup } \\
\text { ation }\end{array}$ & $\begin{array}{c}\% \\
\text { Adults } \\
\text { emerg } \\
\text { ence }\end{array}$ \\
\hline \multicolumn{13}{|l|}{ Dipel } \\
\hline \multicolumn{13}{|l|}{ DF } \\
\hline $2^{\text {nd }}$ & 51 & 47 & 58 & 37.5 & 62 & 64 & 30 & 70 & 68 & 25.6 & 72 & 76 \\
\hline $4^{\text {th }}$ & 42.5 & 58 & 61 & 30 & 70 & 71 & 20 & 80 & 75 & 17.5 & 82 & 78 \\
\hline \multicolumn{13}{|l|}{ W-Bus } \\
\hline $2^{\text {nd }}$ & 43.6 & 55 & 63 & 30 & 70 & 68 & 27.5 & 72 & 72 & 20.5 & 78 & 77 \\
\hline $4^{\text {th }}$ & 37.5 & 62 & 68 & 25 & 75 & 76 & 17.5 & 82 & 79 & 15 & 85 & 79 \\
\hline \multicolumn{10}{|l|}{ Protect } & \multicolumn{2}{|c|}{$\mathrm{O}$} & \\
\hline $2^{\text {nd }}$ & 35.9 & 63 & 76 & 25 & 75 & 80 & 15 & 85 & 82 & 7.7 & 90 & 89 \\
\hline $4^{\text {th }}$ & 30 & 70 & 86 & 20 & 80 & 84 & 7.5 & 92 & 89 & 5 & 95 & 92 \\
\hline \multicolumn{13}{|l|}{ Biofly } \\
\hline $2^{\text {nd }}$ & 38.5 & 60 & 71 & 27.5 & 73 & 76 & 20 & 80 & 84 & 12.8 & 85 & 88 \\
\hline $4^{\text {th }}$ & 32.5 & 67 & 81 & 20 & 80 & 81 & 12.5 & 87 & 83 & 10 & 90 & 91 \\
\hline \multicolumn{13}{|l|}{ Control } \\
\hline $2^{\text {nd }}$ & - & 95 & 94.7 & - & 97 & 95 & - & 97.5 & 94.9 & - & 97.5 & 100 \\
\hline $4^{\text {th }}$ & - & 97.5 & 97.4 & - & 92.5 & 94.5 & - & 97.5 & 100 & - & 97.5 & 100 \\
\hline
\end{tabular}

Table 4. Initial and residual effect of the tested Bt and B.bassiana formulations against $2^{\text {nd }}$ and $4^{\text {th }}$ instar larvae of $H$. brunneipennis at 6 days after treatment

\begin{tabular}{|c|c|c|c|c|c|c|c|c|c|c|c|c|}
\hline \multirow[b]{4}{*}{$\begin{array}{c}\text { Formul } \\
\text { ations }\end{array}$} & \multicolumn{12}{|c|}{ Accumulative larvae mortality after indicating time intervals(days) } \\
\hline & \multicolumn{3}{|c|}{ Initial kill } & \multicolumn{9}{|c|}{ Residual effect } \\
\hline & \multicolumn{3}{|c|}{ Accumulative 2 day } & \multicolumn{3}{|c|}{ Accumulative 4 day } & \multicolumn{3}{|c|}{ Accumulative 6 days } & \multicolumn{3}{|c|}{ Accumulative 8 days } \\
\hline & $\begin{array}{l}\text { \%Cor } \\
\text { rected } \\
\text { larval } \\
\text { mort } \\
\text { ality }\end{array}$ & $\begin{array}{l}\text { \%Pup } \\
\text { ation }\end{array}$ & $\begin{array}{c}\% \\
\text { Adults } \\
\text { emer } \\
\text { gence }\end{array}$ & $\begin{array}{l}\text { \% Correct } \\
\text { edlarval } \\
\text { mortality }\end{array}$ & $\begin{array}{l}\% \text { Pup } \\
\text { ation }\end{array}$ & $\begin{array}{c}\% \\
\text { Adults } \\
\text { emer } \\
\text { gence }\end{array}$ & $\begin{array}{c}\text { \% Correct } \\
\text { edlarval } \\
\text { mortality }\end{array}$ & $\begin{array}{l}\% \text { Pup } \\
\text { ation }\end{array}$ & $\begin{array}{c}\% \\
\text { Adults } \\
\text { emer } \\
\text { gence }\end{array}$ & $\begin{array}{c}\text { \% Correct } \\
\text { edlarval } \\
\text { mortality }\end{array}$ & $\begin{array}{l}\% \text { Pup } \\
\text { ation }\end{array}$ & $\begin{array}{c}\% \\
\text { Adults } \\
\text { emer } \\
\text { gence }\end{array}$ \\
\hline \multicolumn{13}{|l|}{ Dipel } \\
\hline \multicolumn{13}{|l|}{ DF } \\
\hline $2^{\text {nd }}$ & 60 & 40 & 44 & 52.5 & 47 & 47 & 50 & 50 & 60 & 45 & 55 & 64 \\
\hline $4^{\text {th }}$ & 52.5 & 47 & 53 & 45 & 55 & 59 & 32.5 & 67 & 63 & 27.5 & 72 & 69 \\
\hline \multicolumn{13}{|l|}{ W-Bus } \\
\hline $2^{\text {nd }}$ & 55 & 45 & 50 & 47.5 & 52 & 52 & 45 & 55 & 55 & 37.5 & 62 & 68 \\
\hline $4^{\text {th }}$ & 47.5 & 52 & 57 & 40 & 60 & 62 & 27.5 & 72 & 66 & 20 & 80 & 72 \\
\hline \multicolumn{13}{|l|}{ Protect } \\
\hline \multicolumn{13}{|l|}{$\mathrm{o}$} \\
\hline $2^{\text {nd }}$ & 40 & 60 & 56 & 40 & 60 & 58 & 27.5 & 73 & 69 & 20 & 80 & 78 \\
\hline $4^{\text {th }}$ & 35 & 65 & 65 & 27.5 & 72 & 69 & 20 & 80 & 75 & 10 & 90 & 81 \\
\hline \multicolumn{13}{|l|}{ Biofly } \\
\hline $2^{\text {nd }}$ & 45 & 55 & 54 & 40 & 60 & 58 & 32.5 & 67 & 63 & 25 & 75 & 73 \\
\hline $4^{\text {th }}$ & 47.5 & 52 & 62 & 35 & 65 & 69 & 25 & 75 & 70 & 15 & 85 & 76 \\
\hline \multicolumn{13}{|l|}{ Control } \\
\hline $2^{\text {nd }}$ & - & 95 & 97 & - & 92.5 & 97 & - & 95 & 100 & - & 92.5 & 100 \\
\hline $4^{\text {th }}$ & - & 95 & 100 & - & 97.5 & 92 & - & 97.5 & 100 & - & 97.5 & 100 \\
\hline
\end{tabular}




\section{References}

Abbott, W.S. (1925). Amethod for computing the effectiveness of an insecticide. J. Econ. Entoml., 18(2) : 256-267.

Adham, K. Fatma; Eman, M.Rashad; S.F. Ibrahim and Enas, E. Nasr, 2009. Host plants shifting affects the biology and biochemistry of Spodoptera littoralis( Boisd.) ( Lepidoptera: Noctuidae) .Egypt. Acad. J. Biolog. Sci., 2(1): 63-71.

Ahmed, M. 2009. Observed potentiation between pyrethroid and organosphosphours insecticides for the management of Spodoptera litura (Lepidoptera: Noctuidae). Crop Protection, 28: 264-268.

AL- Doghairi, M. A. and E. A. EL-Hag,2003. Effect of several biopesticides on alfalfa weevil larvae, Hypera brunneipennis (Boheman). Pakistan Journal of Biological Sciences. 6 (8) 777- 781.

Alvarez, A.; Virla, E. G.; Pera, L. M. and Baigori, M. D.2009.Characterizationof native Bacillus thuringiensis strains and selection of an isolate active against Spodoptera frugiperda and Peridroma saucia.Biotechnol. Lett., 31: 18991903.

Asi, M.R., M.H.Bashir, M. Afzal, B.S. Khan, M.A.Khan, M.D. Gogi, K. Zia and M. Arshad, 2012. Potential of entomopathogenic fungi against larvae and eggs of Spodoptera litura (Lepidoptera: Noctuidae) . Pak. Entomol., 34(2): 151-156.

Bhattacharya, A.K.; Mondal, P.; Ramamurthy, V.V. and Srivastava, R.P. 2003. Beauveria bassiana ,A potential bioagent for innovative integrated pest management programme. In: Srivastava, R.P. ( Ed. ), Biopesticides and Bioagents in Integrated Pest Management of Agricultural Crops. International Book Distributing Co. Lucknow 860pp.

Dhir, B.C. , H.K. Mohapatra and B. Senapati, 1992. Assessment of crop loss in groundnut due to tobacco catterpiller, Spodoptera litura (F.) Indian J. Plant Prot., 20 (7- 10) : 215-217.

Duncan, D. B. 1955. The Multiple Range and Multiple F- Test. Biometrics 11: 1- 42.

El- Ghar, G.E.S.A.; Radwan, H. A. S. ; El- Bermany, Z. A.; Zidan, L. T. M. 1995. Sublethal effects of avermectin B1, betaexotoxin of Bacillus thuringiensis and diflubenzuron against cotton leafworm (Lepidoptera: Noctuidae) . J. Appl. Entomol., 119: 309 - 313.

El - Hawary, F. M. and Abd El- Salam, A. M. E. 2009. Laboratory bioassay of some entomopathogenic fungi on Spodoptera littoralis (Boisd.) and Agrotis ipsilon (Hufn.) larvae (Lepidoptera: Noctuidae) Egypt. Acad. J. Biolog. Sci., 2(2) : $1-4$.

Emara, T. E. and Hefnawy, M. A. 2000. Biological activity of some fungal extract against the development of the cotton leafworm Spodopter alittoralis J. Egypt. Ger. Soc. Zool., 33( E ) : 217- 225.

Finney, D. F. 1971. Probit analysis $3^{\text {rd }}$ edition. Cambridge University, London.318PP.

Haggag, Karima,H. E.2013. Changes in protein profile of cotton leafworm ,Spodoptera littoralis, induced by Bt formulations stored at cold and hot storage conditions. Nature and Science ,11 (7): 77- 85

Hammad,S. M. , S. El- Sherif, M. M. Hosny and A. I. El- Deeb. 1967. The biology of Hypera brunneipennis Boh. Bull. Soc. Ent. Egypte. Li. : $251-256$.

Herrnstadt, Corinna and George ,G.Soares,. 1989. Cotton boll weevil, alfalfa weevil, and corn rootworm via contact with a strain of Bacillus thuringensis:4, 797, 276.

Kamel, Aida S. ; Mona, Ab - El Aziz F. and Nehad, El- Barky M.. 2010. Biochemical effects of three commercial formulations of Bacillus thuringiensis (Agerin, Dipel 2x and DipelDf ) on Spodoptera littoralis larvae . Egypt. Acad. J. Biolog. Sci., 3 (1) : 21- 29.

Karima, H. E. Haggag, 2013. Changes in protein profile of cotton leafworm, Spodopter alittoralis, induced by Bt formulations stored at cold and hot storage conditions. Nature and Science 11 (7) 77- 85.

Karthikeyan, A. and Selvanarayanan, V. 2011. In vitro efficacy of Beauveria bassiana (Bals.) Vuill. And Verticillium lecanii (Zimm) Viegas against selected insect pests of cotton. Science and Technology, 3 (2): 142- 143.

Kaur, S. 2000. Molecular approaches towards development of novel Bacillus thuringiensis biopesticides. World Journal of Microbiology and Biotechnology, 16: 781- 793.

Meshrif, W. S. ;Barakat, E. M. S. ; Rohlfs, M. ; Shehata, M. G. ; Seif, A. I. and Hegazi, M. A., M. 2007. Evaluation of testing four hyphomycete fungi against the development of the cotton leafworm Spodoptera littoralis (Lepidoptera: Noctuidae). J. Egypt. Acad. Soc. Environ. Develop., 8(3) : 11- 20.

Mohammed A. Al- Doghairi and Eltayeb El Hag. 2003. Effect of several biopesticides on alfalfa weevil larvae, Hypera brunnipennus (Boheman). Pakistan Journal of Biological Sciences. 6 (8) 777- 781 .

Mohamed, E. M. ,Hanan, F. Abdel- Hafez and MahasenA. Abdel Aziz. 2010. Effect of some chemical additives on the potency of Bacillus thuringiensis against the cotton leafworm Spodoptera littoralis. Egypt. J. Agric. Res., 88(1), 103-112.

Mohamed, A. M. and Mahmoud, F. M. 2008. Effect of biorational insecticides on some biological aspects of the Egyptian cotton leafworm 
Spodoptera littoralis (Boisd.) (Lepidoptera: Noctuidae). Plant Protect. Sci., 44: 147- 154.

Prayogo, Y., W.Tengkano and D. Marwoto, 2005. Prospect of entomopathogenic fungus Metarhizium anisopliaeto control Spodoptera littoralison soybean. J. LitbangPertanian, 24(1) : 19-26.

Sanchis V.; Gohar, M .; Chaufaux, J. ; Arantes, O. ; Meier, A. ; Agaisse, H. ; Cayley, J. and Lereclus, D. 1999. Development and field performance of a Broad- Spectrum Nonviable Asporogenic Recombinant Strain of Bacillus thuringiensis Greater Potency and UV
Resistance. Applied Environmintal Microbiology, 65 (9) : 4032- 4039.

Shelton, A. M.; Robertson, J. L. ; Tang, J. D. ; Perez, C.;Eigenbrode, S. D.; Preisler, H. K.; Wilsey, W. T. and Cooley, R. J. 1993. Resistance of diamondback moth (Lepidoptera :Plutellidae ) to Bacillus thuringiensis sub species in the "eld. Journal of Economic Entomology, 86: 697705 .

Souza, Jr, J. D. A. de; Jain, S.; de Oliveira, C. M. F.; Ayres,C. F. and Lucena, W. A. 2009. Toxicity of Bacillus thuringiensis israeliensis - like strain against Spodoptera frugiperda .BioControl, 54: 467- 473. 


\section{الملذص العبى \\ تقييم لبعض المستحضرات التجارية على دودة ورق القطن وسوسة ورق البرسيم}

$$
\begin{aligned}
& \text { نارمين أحمد يوسف }{ }^{1} \text { و عاطف عبد الجيد² } \\
& \text { قسم وقاية النبات - كلية الزراعة -جامعة الفيوم - الفيوم - مصر . }
\end{aligned}
$$

تم تقيم فاعلية بعض المستحضرات البكتبرية ( الداييل دى إف ، دابيلو بص، بروتيكتو ) والفطرية بيوفلاى ضد كل من العمر اليرقى الثنانى والرابع

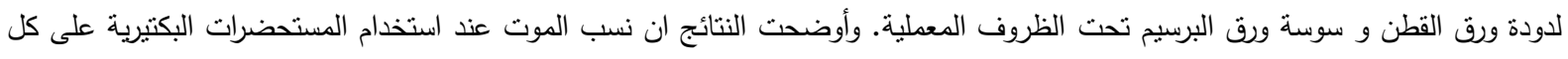

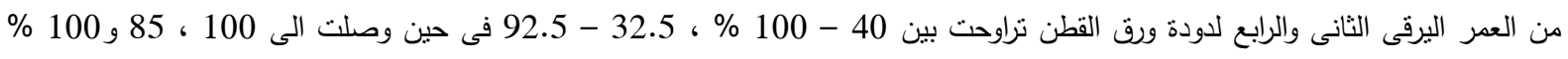

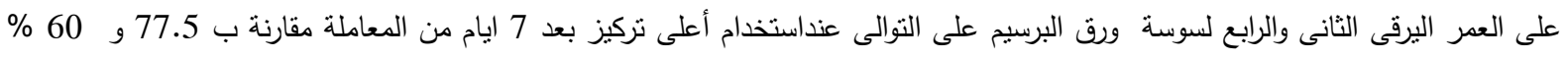

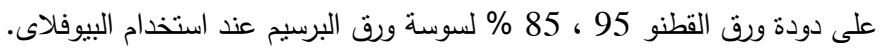

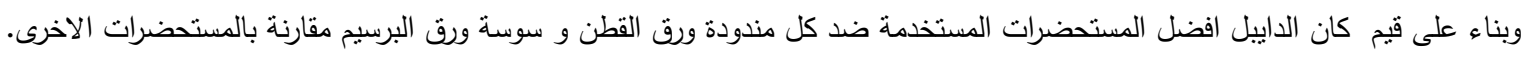
كما إنخفت نسب خروج كل من العذارى والحشرات الكاملة عند المعاملة بالمستحضرات السابقة مقارنة بالكنترول. 